\title{
To Be or Not to Be God-The Issue of Authorial Power in Dostoevsky ${ }^{\dagger}$
}

\author{
Alexander Zholkovsky
}

check for updates

Citation: Zholkovsky, Alexander. 2021. To Be or Not to Be God-The Issue of Authorial Power in Dostoevsky. Religions 12: 506. https://doi.org/10.3390/rel12070506

Academic Editor: Dennis Ioffe

Received: 3 June 2021

Accepted: 30 June 2021

Published: 7 July 2021

Publisher's Note: MDPI stays neutral with regard to jurisdictional claims in published maps and institutional affiliations.

Copyright: (C) 2021 by the author. Licensee MDPI, Basel, Switzerland. This article is an open access article distributed under the terms and conditions of the Creative Commons Attribution (CC BY) license (https:/ / creativecommons.org/licenses/by/ $4.0 /)$.
College of Letters, Arts and Sciences, University of Southern California, Los Angeles, CA 90007, USA; alik@usc.edu

+ This is a revised version of an article originally published in Russian in a collected volume Paradoksy russkoi literatury. Edited by Wolf Shmid and Vladimir Markovich. St-Petersburg: Inapress, 2001, pp. $234-47$.

\begin{abstract}
This paper problematizes the now widely accepted concept of Dostoevsky's dialogism, which alleges the 'Author's' equal empowerment of all his characters. Using examples from Crime and Punishment and The Brothers Karamazov, Zholkovsky focuses on instances of 'scene-staging' based on the 'scripts' devised and enacted by some characters, that are 'read,' with varying success, by their targets. He documents the resulting 'discursive combat' among the characters, with special attention paid to those 'playing god' and thus, the more 'authorial' among them. In several cases, the would-be 'divine' manipulation is shown to be consistently subverted by the Dostoevskian narrative. However, in one instance, where Aliosha Karamazov charitably scripts Captain Snegirev's behavior, the ensuing discussion of this episode, in Aliosha's conversations with Lise Khokhlakova, upholds Aliosha's right to play god with the Other- "for the Other's own good", of course (not unlike the Grand Inquisitor).
\end{abstract}

Keywords: authorial power; scripting others; reading each other; discursive combats; playing god; Raskolnikov; Luzhin; Aliosha Karamazov; the Grand Inquisitor

'God is dead, long live God, that is, Man'. This slogan by various voices resounded in Russian even before Friedrich Nietzsche.

Ivan Turgenev's Bazarov claims that the nihilistic 'cause' needs such slaves of its discourse as Sitnikov, as noted to Arkady:

-You, brother, are still stupid, I see. We need Sitnikovs. I, understand this, I need such dummies. It's not the Gods' job to fire pots ... !

-"Wow," Arkadii thought to himself, and only then did he discover the bottomless abyss of Bazarov's ego.- " You and I are gods, aren't we? That is to say, you are a god, while I am just a dummy?"

-Yes, Bazarov repeated sullenly, You are still stupid. (Fathers and Sons, chp. 19, vol. 3, pp. 202-3; Turgenev 1961-1962)

(-Ты, брат, глуп еще я вижу. Ситниковы нам необходимы. Мне, пойми ты это, мне нужны подобные олухи. Не богам же всамом деле горшкиобжигать! .. .

Эre, re! . . . - подумал про себя Аркадий, и тут только открылась ему ... вся бездонная пропасть базаровского самолюбия.-Мы, стало быть, с тобой боги? то есть-ты боr, а олух уж не я ли?

-Да-повторил угрюмо Базаров-тыеще глуп.)

Bazarov's impertinent discursive move consists of reversing the perspective of the Russian proverb, "It doesn't take Gods to fire pots", which is, in fact, quite reverent towards gods-in the spirit of rendering to potters the things that are potters' and to God the things that are God's. Incidentally, Turgenev's choice of this proverb has rich theological overtones, 
since according to one of the biblical versions ("And, God Yahweh created Man from the dust of the ground ... "; Genesis 2:7), "God's creation of Man [wayyisar] is like a potter's work [yosar]" (Shifman 1993, vol. 58, p. 270).

In an opposite, kenotic, gesture, Leo Tolstoy, sated with his absolute power over the text, would wonder: "Who Should Learn to Write from Whom: Peasant Kids from Us or We from Peasant Kids?" and even signed some of the Iasnaia Poliana peasant schoolkid's essays-as containing the ultimate truth.

These two moves - up and down the ladder of discursive authority-merge in the figure of the Author. The Author both acknowledges his inevitable human limitations, akin to those of his characters, and acts as the creator of an artistic world where these characters walk under him as under God. Thus, Nikolai Gogol confessed that his comic characters were his "own trash ... demoted from generals to privates" (Selected Passages from Correspondence with Friends, chp. XVIII, p. 3; Gogol' 1976-1979, vol. 6, pp. 259-60), and yet he was accused of authorial despotism by a literary descendant of one of these "privates": the main protagonist of Fedor Dostoevsky's Poor Folk (Bocharov 1985, pp. 161-209).

Abolishing the distance between the divine top and the human bottom takes different forms. By projecting himself into Platon Karataev or a peasant kid, the Author sheds his social and institutional prerogatives, strips off his epaulettes, goes slumming. Often such reversal of the power hierarchy is accompanied by a Rousseauist emphasis on the soulful, 'soilist', intuitive, and other advantages of identifying with the 'social bottom'. Another variant is the author's co-opting of the 'morally low,' that is, an attempt to place representatives of 'evil' in the service of the 'good' and its narrative discourse-in the spirit of John Milton's use of Satan and Johann Wolfgang von Goethe's utilization of Mephistopheles. Such, for instance, was the intention of the author/narrator of Dead Souls, in his own words, to gainfully "harness" a true "scoundrel", i.e., Chichikov (Dead Souls, I, chp. 11; Gogol' 1976-1979, vol. 5, p. 214).

This harnessing was twofold. In the distant Dantesque perspective of Gogol's unrealized project, the "scoundrel" was to become the engine of Russia's providential transfiguration; while in the immediate 'infernal' reality of the book's first volume, the "scoundrel" was trusted with the better part of plot-building. Co-authorship with a trickster-protagonist has a venerable literary pedigree; and ethical problems do arise when purely narratorial services rendered to the author by the protagonist's deceitful artistry lead to an ambiguous moral symbiosis.

According to Mikhail Bakhtin, Dostoevsky's radical contribution to literary discourse consisted in the carnivalesque overthrow of the author's 'divine' power over his characters: conferring on "privates" equal dialogical rights with the "generals", and thus empowering them as narrators and ideologically authoritative personae. One of Dostoevsky's favorite plot devices was to have a rationalistic manipulator fail as a result of arrogantly ignoring the human unpredictability of the 'Other', usually a modestly 'ordinary' character. (Dostoevsky might have learned this from the way Gogol had Chichikov exposed by none other than Korobochka, the most obtuse of his gentlefolk partners).

An important aspect of this motif is its focus on discourse. The manipulator 'prescribes' to his 'naïve' partner a certain 'script' and does so in an 'authorial' manner that schematizes, objectifies, 'automatizes' him. However, the latter, being in touch with 'reality,' 'reads' and 'rewrites' the script in his own way, thereby refuting his 'automaticity' and thus beats the 'author' of the script at his own game of script-writing. Examples abound, e.g.:

-Raskolnikov's skillful, but eventually failed, attempt to pretend to laugh nonchalantly as he enters, along with Razumikhin, Porfirii's apartment;

-Smerdiakov's surprising Ivan and others by suddenly speaking up-like the "Balaam's donkey"; 
-and the title character of "A Gentle Creature" similarly surprised her husband, who had planned their entire life together in advance and on seeing her dead body thought he was "only five minutes late".

This Dostoevskian invariant was eloquently formulated by Fed'ka Katorzhnyi, an archetypal 'low-life' character, in his conversation with Stavrogin about Peter Verkhovenskii:

"[He] has ... learned all God's pre-destinations but he is also subject to criticism ... If he has said a man is a scoundrel, he knows nothing about him but that he is a scoundrel. Or if he has said one is a fool, he has no other title for that man but a fool. While I may be only a fool on Tuesdays and Wednesdays, but on Thursday I am smarter than him ... Now he knows about me that I am in a bad need of a passport ... so he thinks he's got my number. He ... has it very easy living in the world, 'cause he just imagines a person and then lives with one as such" ('The Demons', II, 2; Dostoevsky 1972-1990, vol. 10, p. 205).

(“Петр Степаныч < . . > все божии планиды узнал, а и он критике подвержен... У [неro] коли сказано про человека: подлец, так уж кроме подлеца он про неro ничеro и не ведает. Али сказано-дурак, так уж кроме дурака у него тому человеку и звания нет. А я, может, по вторникам да по средам только дурак, а в четверг и умнее еro ... Вот он знает теперь про меня, что я оченно паспортом скучаю ... так уж думает, что он мою душу заполонил. Петру Степановичу ... оченно легко жить на свете, потому он человека сам представит себе, да с таким и живет.")

'The war of the scripts' is by definition: strategic, discursive, and hierarchical. The question is always, who will outdo whom in 'reading' and 'rewriting' the other. And the carnivalesque mode of Dostoevsky's narrative inevitably generates paradoxes. The protagonist-narrator of "Notes from Underground," whose philosophical kinship with the implied (and, indeed, the real) author poses a serious problem, is referred to as a "paradoxalist." And, of course, Raskolnikov, true to his telling surname, is a walking paradox: a moral immoralist, a clever fool, an under-Overman.

Not all of Dostoyevsky's paradoxes are equally elaborate and well-thought-through. Some look like involuntary contradictions, dictated by narrative conventions and the Zeitgeist; others, fraught with meaning, are due to the author's own inconsistency. The former case is exemplified by the Victorian purity of Dostoevsky's fallen women: Sonechka Marmeladova's profession, rhetorically so important in Crime and Punishment, is never actually plied by her in the plot; likewise, a close reading of The Brothers Karamazov leaves one with the impression of the fatale Grushenka's immaculate chastity. In what follows, we will focus on the latter case: the unplanned dead ends of the Author's innovative attempt to renounce his divine powers.

Let us turn to Part V of Crime and Punishment, Chapters 1 and 3, where Luzhin accuses Sonya, in dramatic fashion, of having stolen money from him. The episode unfolds as a series of discursive duels, with unexpected outcomes that end up undermining the power claims of the arrogant 'script-writers'.

Chapter 1 (Dostoevsky 1972-1990, vol. 6, pp. 276-90) begins with Luzhin's regretting he had miscalculated in trying to get Dunia cheaply ("why the hell did I get so yid-like greedy?"; p. 277) and being angry at Raskolnikov for upsetting those plans. The news that Raskolnikov is coming to the wake gives Luzhin "an idea" (p. 278). This is followed by a description of his relationship with Lebeziatnikov, with whom he is staying: he begins by flattering him as a bearer of a new authoritative discourse, but soon recognizes his harmless adherence to an ideological vogue. As Lebeziatnikov spouts his ridiculous utopian ideas about marriage, Luzhin keeps counting money while venomously teasing him. Then, at Luzhin's request, Lebeziatnikov brings in Sonia, and Luzhin gives her a ten-ruble bill. Delighted by his kindness, Lebeziatnikov (who "heard and saw everything"; p. 288) 
forgives him his mocking tone and launches into utopian rants again. Luzhin chuckles again, but "even Lebeziatnikov finally ... noticed" that he was "thinking of something else... and was rubbing his hands" (p. 290).

The discursive dynamics here is approximately as follows:

(1) Luzhin has lost to Dunia and Raskolnikov.

The author is on their side ${ }^{1}$, despite Raskolnikov's sharing some features with Luzhin.

(2) Luzhin plots against Raskol'nikov.

The author prefers Raskol'nikov.

(3) Luzhin mocks Lebeziatnikov, who looks foolish.

The author uses one negative character to defeat another, a deliberate paradox by Dostoevsky (in the words of another of Dostoevsky's 'authorial' characters, Ivan Karamazov, "One viper eats another viper"; IV, 5; Dostoevsky 1972-1990, vol. 14, p. 170; incidentally, Lebeziatnikov is, in essence, a Dostoevskian version of Turgenev's Sitnikov, while Luzhin and Raskol'nikov in tandem form an approximate counterpart of Bazarov).

(4) Luzhin presents himself in a positive light in front of Sonia and Lebeziatnikov.

The author makes it clear that there may be something behind this.

In Chapter 3 (vol. 6, pp. 300-11), Luzhin publicly accuses Sonia of stealing a 100ruble bill from him, calls on Lebeziatnikov as a witness, and insists that Sonia be taught a lesson. Katerina Ivanovna then offers to search Sonia, turns her pockets inside out, and a bill falls to the floor. Luzhin triumphs over Sonia and Raskolnikov and declares that the lesson has been taught, so he is willing to generously close the case. However, then Lebeziatnikov accuses Luzhin of meanness, stating that he saw Luzhin surreptitiously put the money in Sonia's pocket, which he, Lebezitnikov had then took to be an act of secret beneficence. However, Luzhin denies this, pointing out that he has no motive for such actions. Lebezyatnikov launches into ridiculous ethical assumptions about the motives of Luzhin, who, in turn, accuses him of personal ideological ill-will towards him. Lebeziatnikov is at a loss as to what to think, when Raskolnikov speaks up to unravel Luzhin's scheme: by disgracing Sonia he tried to undermine Raskolnikov's authority in the eyes of his sister.

In terms of the war of the scripts, the following is happening:

(1) Luzhin tries, according to a script he has devised, to teach Sonia and Raskolnikov a lesson while parading his own generosity.

The author keeps ambiguously silent.

(2) Luzhin's script stumbles upon Lebezyatnikov's unforeseen abandoning of his prescribed role, unexpected even for Lebeziatnikov himself, who thus takes the upper hand in his personal tug-of-war with Luzhin.

The author sides with the good and honest fool Lebeziatnikov (in an invariant Dostoevskian paradox).

(3) Luzhin, however, once again outplays Lebeziatnkov, who is unable to 'read' his motives, and imputes to Lebeziatniukov base intentions.

The author implicitly prefers Lebeziatnikov.

(4) Raskolnikov defeats Luzhin by correctly reading his script.

The author sides with Raskolnikov.

Raskolnikov's triumph, both practical and moral, crowns the pyramid of rival scripts but does not abolish the ambiguity of his entire discourse strategy. In the next chapter, he will try to justify his immoralism in the eyes of Sonia by invoking her own defenselessness in the world of Luzhins, while confessing to her his crime and asking her for support. His, a criminal's, successful advocacy of Sonia and indictment of Luzhin form one of the major paradoxes of Crime and Punishment. And, in the larger scheme of things, this episode is a negative foreshadowing of the subsequent speeches of Sonia, Porfirii and Svidrigailov, who, each in their own way, will 'read' and refute his script (first published as an article and then enacted in real life).

In this discursive respect, the relationship between Raskolnikov and Svidrigailov is of particular significance. Despite his general immoralism and self-destructive end, 
Svidrigailov is, just like Sonia and Porfirii, complicit in the novel's authorial agency. Sonia, of course, carries the main load as the book's principal righteous and sermonizing Christian; but her potential moral authoritarianism is softened by her sinful profession, her general humility, and, most importantly, by the lack of scriptural and directorial manipulation on her part: she persuades Raskolnikov by straightforward arguments and her personal moral integrity.

Porfirii embodies a rationalist stance presented in a positive light, which is rare in Dostoevsky's world. He arrives at an adequate reading of Raskolnikov on his own-in contrast to Sonia, who relies on faith in God and gets a reading of Raskolnikov from Raskolnikov himself and only then intuitively makes a deeper moral sense of it.

Svidrigailov, on the other hand, has much in common with Raskolnikov and so he owes his correct reading of him not only to the coincidental eavesdropping but also to an empathy based on their moral kinship (inherent in Dostoevsky's polyphonic portrayal of characters). Svidrigailov's penetration into the unconscious paradoxes of Raskolnikov's mentality is emblematized by his remark about Raskolnikov's apparent conviction that "eavesdropping is all bad, while cracking old women's skulls is OK" (VI, 5; 6: 373).

Here, Svidrigailov achieves the kind of discursive victory over Raskolnikov that the author had denied to Luzhin (this is yet another round in the ongoing war of the scripts). The fact is that Luzhin's soulless and mechanistic bourgeois mentality is a greater anathema to Dostoyevsky than Svidrigailov's demonic and, therefore, somewhat romantic, i.e., 'spiritual,' cynicism. Besides, as has been noted (albeit without decisive proof), Svidrigailov's predilection for underage girls (Nabokov's future "nymphets") may have been a reflection of his author's similar tastes.

Last but not least, the character of Svidrigailov boasts yet another 'authorial' function: his role in arranging the novel's denouement and its protagonists' future destinies. To begin with, by his suicide, he frees Dunia for marrying Razumikhin (and Raskolnikov, from having to protect her from him). What is more, he takes upon himself the financial settlement not only of his own newly found bride, but also of Sonia and her siblings and even of Raskolnikov ("When I give you, it is all the same as if I give him"; VI, 6; 6: 385). Thereby he fulfils a typically authorial function, and Dostoevsky, so to speak, does not shy away from soiling his hands with Svidrigailov's money. This-after having presented money in a consistently negative light throughout the plot: in the hands of Alena Ivanovna the old moneylender, Raskolnikov the robber-murderer, Luzhin the would be bridegroom of Dunia and accuser of Sonia, Marfa Petrovna as Svidrigailov's "landladyowner" ("khoziaika"), and of Svidrigailov himself as Dunia's potential seducer!

Overall, however, the 'authorial' functions in the novel are distributed among the several quasi-authorial characters, who are 'disempowered' in one way or another, so that no sense of unquestionable, authoritarian control emerges. Even in the Epilogue, which has been frowned upon by critics for having been "fixed" by the author, there is no authorial manipulation of Raskolnikov by other characters. In the figure of Sonia one can see a number of stereotypes ('a strong Russian woman', 'a hooker with a heart of gold', 'a saintly sinner'), but none of the many types of Dostoevsky's 'manipulative scripters'.

For a more challenging case, let us turn to The Brothers Karamazov- the end of Book IV and the beginning of Book V (Dostoevsky 1972-1990, vol. 14, pp. 178-202). We will focus on Aliosha, the author's favorite positive hero, a disciple of the perfectly righteous (although kenotically "stinking" once a corpse) elder Zosima.

Confronted by schoolboys and Iliushechka, who had bravely stood up for his father, staff-captain Snegirev humiliated by Dmitry Karamazov, and, among other things, bit Aliosha on the finger, Aliosha visits Snegirev at home and meets him and his variously sickly family (chp. 6, "A Laceration in a Hut"). Snegirev meets him with defiance, seeing in his visit a continuation of Dmitrii's aggression, and Iliusha shouts that Aliosha has, of course, come to complain about him. Aliosha tells how Iliusha threw a stone at him and bit him, and Snegirev, sneering in the spirit of mock modesty, offers to have Iliusha flogged right there and then. But then, he promptly scoffs at the very idea of flogging his son- "for 
your complete satisfaction" - and probably even cutting off "four of my own fingers ... with this very knife" ("four fingers ... will be enough to quench your thirst for vengeance, won't they, so you won't demand the fifth, sir?'; vol. 14, p. 183). Aliosha says that he has not come to complain, but rather to convey that Dmitri has repented and wants to beg forgiveness and is ready to publicly kneel before Snegirev. "Pierced to the heart" - replies Snegirev (p. 183). Nevertheless, in spite of Iliusha's objections, Snegirev goes out with Aliosha to talk "outside these walls".

The war of discourses here is so far of the usual Dostoevskian sort:

(1) The 'little man' (Snegirev), humiliated by a 'significant person' ("his lordship" Dmitri; p. 183), contrary to expectations, turns out to be morally, intellectually and verbally sophisticated (especially in comparison with the script of "The Overcoat" - as seen in Poor Folk), indeed, uncompromisingly bold, as he plays out a scene of consummate mockery at the expense of the script he attributes to his opponent.

The author presents this from the point of view of Aliosha, whose unquestionably good intentions are known to the reader.

(2) Aliosha neutralizes Snegirev's game, showing real humility-on behalf of his brother, and most importantly, on his own behalf; Snegirev hesitates, but Iliusha does not give up his confrontational stance.

The author sympathizes with both sides and retains hope for their reconciliation.

In the following chapter ("And in the Open Air"; IV, 8; 14: 185-93), Snegirev frankly tells Aliosha about himself, about the impossibility for him to sue Dmitrii, about the wounded pride of Iliusha, who "alone against all rebelled for his father" (p. 187) and about Iliusha's plans to grow up and take revenge on Dmitri ("I will strike him down and tell him: I could have killed you now, but I forgive you"; p. 189). Aliosha repeats that his brother has repented and is ready to ask for forgiveness, while his bride, Katerina Ivanovna, also insulted by Dmitrii, asks Snegirev to accept money ("from her alone, not from Dmitrii... And not from me... This means that the sister goes to her brother with help... She specifically instructed me to persuade you to accept these two hundred rubles from her as from a sister. No one will know about this... You have a noble soul... you must understand this...!"; p. 190). Snegirev at first agrees to accept the money, although asking, "I will not then be a scoundrel, will I?" (p. 191); he makes plans of using the money for the benefit of the family and Iliushechkas', and worries whether "the money will suffice" (to which Aliosha promises to add as much as needed of his own; p. 192). Yet, Snegirev ends up refusing, with perverse pride ("And what would I tell my boy, if I took money from you for our shame?"; p. 193), and, "throwing both crumpled bills on the sand-did you see?" (p. 193), Snegirev asks Aliosha to tell those who sent him that he is "not selling his honor!" and runs off (p. 193). Aliosha picks up and smooths out the banknotes.

The discourse dynamic here is as follows:

(1) Aliosha's Christian, 'brotherly-sisterly' script begins to materialize, as mutual understanding emerges in the course of a heart-to-heart talk "in the open air".

However, the author makes it clear that not everything is going smoothly. Firstly, Aliosha acts not only on his own initiative, but according to the script of Katerina Ivanovna, whose motives are not simple and who in no way embodies Christian humility. Secondly, Snegirev keeps slipping into unhealthy 'alien' discourses: of an exaggeratedly heroic scenario (in the spirit of Alexander Pushkin's Sylvio), of Iliusha's anticipated revenge, and of his own exaggeratedly sentimental utopian plans about using the money.

(2) Snegirev thwarts the fulfillment of Aliosha's script (in accordance with Dostoevsky's favorite paradox of a 'modest' character evading the line of conduct prescribed for him by a 'cleverer' partner). He does so by following yet another ready-made script, once again borrowed from Pushkin: the station master's throwing away the money received "for Dunia" from Minsky. As Aliosha picks up the money, he varies this subtext in an interesting way: in Pushkin's short story, the money is also picked up — not by Minski, but by some well-dressed accidental passer-by.

The author sides with Aliosha, but his position is not fully clear yet. 
Book V opens with a chapter in which Aliosha tells Lise Khokhlakova about what happened.

-"Well ... You gave that money, and now how is this unfortunate person?"

- "That is just it, I did not give it, and there's a whole story here", Aliosha answered ... He spoke ... well and thoroughly. He used to ... when Lise was a child, he liked ... to tell what had just happened to him then, or from what he had read, or to remember from his childhood. Sometimes they even dreamed together and wrote whole novellas together ... Now it was as if both of them were suddenly transported back in time ... Lise was extremely touched by his story. Aliosha with fervent emotion managed to draw before her the image of Iliushechka, and then explained in detail why Snegirev refused the money: he "hated" Aliosha, before whom "he was ashamed that he had bared the depth of his soul" (p. 196) and who had committed the mistake of injuring his pride with the offer "to give[s] from his own as much as needed." But, Aliosha continued, this mistake was "for the best", for if Snegirev had taken the money by overstepping his pride, he would have returned it the next day; while now that his pride had been won back, he would, on the contrary, be ready to accept it with a clear conscience.

-“And that's when I am going to show up, meaning, yes, you're a proud man, you've proven it, well, now take it and forgive us. And then he will take it!"

In a kind of rapture, Aliosha exclaimed: "And then he'll take it!" Lise clapped her hands.

-“... Oh, Aliosha, how do you know all this? You're so young, and you already know what's in everyone's heart. I would never have thought this up."

-“The main thing is to convince him now that he's on an equal footing with all of us, despite the fact that he takes money from us... and not only on an equal footing, but even on a higher footing..."

-“'On the higher ground' is lovely, Alexei Fedorovich... But... Isn't there in all this reasoning of ours, that is, of yours... better ours... some contempt for him-in the fact that we are now parsing his soul in this way, as if looking down on him, eh? That we've decided for sure now that he'll accept the money, eh?"

-"No, Lise, no disdain," said Aliosha firmly, as if he had prepared for the question.-- "Because we, too, are same as he, no better... You know, Lise, my elder once said: people should always look after people like after children, and after some, like after patients in hospitals". (p. 197)

(-Что же ... отдали вы эти деньги, и как же теперь этот несчастный? ...

-То-то иесть, что не отдал, и тут целая история-ответил Алеша ... Он говорил ... хорошо и обстоятельно. Он и прежде ... еще в детстве Lise, любил ... рассказывать то из случившегося с ним сейчас, то из прочитанноro, то вспоминать из прожитоro им детства. Иногда даже оба мечтали вместе и сочиняли целые повести вдвоем . . . Теперь они оба как бы вдруг перенеслись в прежнее ... . время . . . Lise была чрезвычайно растроraна ero рассказом. Алеша с горячим чувством сумел нарисовать перед ней образ 'Илюшечки', а затем подробно объяснил, почему Снегирев отказался от денеr: он «возненавидел» Алешу, перед которым «стыдно стало за то, что он так всю душу мне показал» (р. 196), и который совершил ошибку, уязвив еro ropдость предложением «да[ть] из своих сколько угодно». Но, продолжил Алеша, эта ошибка «к лучшему», ибо если бы Снегирев взял деньrи, переступив через свою гордость, то на другой день вернул бы их, теперь же, коrда ero ropдость уже отыrрана, он, наоборот, будет готов принять их с чистой совестью.

-А я-то вот тут и явлюсь: Вот, дескать, вы гордый человек, вы доказали, ну теперь возьмите, простите нас'. Вот тут-то он и возьмет! 
-Алеша с каким-то упоением произнес: “Вот тут-то он и возьмет!” Lise захлопала в ладошки.

- ... Ах, Алеша, как вы все это знаете? Такой молодой и уж знает, что в душе. Я бы никогда этого не выдумала..

-Ero, rлавное, надо теперь убедить в том, что он со всеми нами на равной нore, несмотря на то, что он у нас деньги берет... и не только на равной, но даже на высшей ноre...

-“На высшей ноre”-прелестно, Алексей Федорович ... но . . н нет ли тут во всем этом рассуждении нашем, то есть вашем ... нет, уж лучше нашем.. нет ли тут презрения к нему, к этому несчастному ... в том, что мы так ero душу теперь разбираем, свысока точно, а? В том, что так наверно решили теперь, что он деньги примет, a?

-Нет, Lise, нет презрения-твердо ответил Алеша, как будто уже приготовленный к этому вопросу ... . -Потому что ведь и мы такие же, не лучше ... Знаете, Lise, мой старец сказал он раз: за людьми сплошь надо как за детьми ходить, а за иными, как за больными в больницах.)

In Chapter 5, Book X, the main narrator informs us that Snegirev accepted those two hundred rubles from Katerina Ivanovna exactly as Aliosha had predicted. "And then Katerina Ivanovna ... visited their flat herself ... After that her hand hasn't grown scarce, and the staff-captain himself ... forgot his former haughtiness and humbly accepted alms" (vol. 14, pp. 486-87).

In contrast to all the previous cases, this episode is not so much an unfolding combat of scripts but rather an authorial/critical meta-discussion of a discourse combat that had already taken place (between Aliosha and Snegirev) and of the forecast (by Aliosha) of its expected denouement.

(1) The meta-discourse mode is set at once, not only by the very format of the retelling/discussion, but also by a direct reference to the usual practice of such 'literary' meetings and joint writing of "novellas", as well as by the use (in the author's narrative) of literary-critical terms, such as "he managed to draw her an image of Iliushechka".

The author, by transferring part of the authorship to his favorite hero, complicates the narrative hierarchy, maintaining a certain distance from Aliosha 'the author', for instance, by noting his "rapture" ("upoenie") with his own script.

(2) The relationship between the two interlocutors is not limited to Lise's idyllic agreement with Aliosha (who is older and has a certain moral mandate based on his closeness to Zosima), emphasized by her respectfully phrased 'co-authorial' statements ("so young, and you already know what is in a heart"; "in all this reasoning, that is, ours, no, yours, no, better ours"). Lise, the "little devil," plays (here and elsewhere) the role of the devil's advocate, teasing and provoking Aliosha in every way about his "monastic holiness" and revealing in his speech a characteristic 'hierarchical' clause (about the "equal/higher footing"). In the end, she poses the ultimately troubling question, namely: Does not Aliosha's 'omniscient parsing from above' (a few pages later, he will return again to the "martyr's" question of "anatomizing" another person's soul; 199), in fact, calculating and directing the behavior of another person-does not this mean "contempt" for Snegirev (that is, in today's terms, objectifying a live human being and his/her unfinished discourse).

The author, sensing, perhaps, that this is the mother of all questions for a truly dialogic poetics, lets Lise develop her position quite eloquently and even with caustic irony.

(3) Aliosha, however, is not taken by surprise by Lise's question (unlike the usual case, where the 'strong' partner is caught unawares by the 'weak'). He "himself had thought about this on his way here," and now gives her a prepared (!) answer: yes, it is possible and even necessary to manipulate people for their own good, provided we remember that we are "just like them, no better." This argument is supported by nothing else but a reference to the authority of the elder (Zosima), which is enough for Lise: "Ah... sweetie, let us look after people as if they were ill!" (p. 197; Lise omits the second component of the elder's 
instructions (central to the novel that is about the relationship between fathers and sons): "we should look after them like after children"; in fact, in the person of Snegirev, Aliosha adopts—as a son-one of the novel's distinctly paternal figures.

The author implicitly but clearly endorses this position: Zosima's moral authority in the novel is never in doubt, and Aliosha's remark is accompanied by the narrator's words: "Aliosha answered firmly."

This is the deadend paradox of Dostoevsky alleged dialogicity, which this article set out to demonstrate. ${ }^{2}$ Aliosha, acting in an authorial role, 'reads' in the heart of another, 'little,' man, assumes a parental, authoritative, practically 'divine' role towards him and successfully scripts for him his 'mechanical' behavior (implementing one after another the two opposite versions of Dostoyevsky's typical 'action in reverse': in Book IV, first, humility, then pride, in Book X, first pride, then humility) and "firmly" bolsters his directorialism with a "prepared" reference to 'authority.' It is possible, of course, to invoke the 'openness' of the text, the questionable traits in Aliosha's character ("I may not believe in God"; p. 201), his subsequent failure to prevent the murder of his father and in the conviction of Dimitri in court, but this does not eliminate the problem. The author lets Aliosha play God and get away with it.

In the context of the novel as a whole and of Dostoevsky's other narratives, this episode looks all the more paradoxical as it echoes them as an unexpected variation on familiar themes. Note that, like in the cases of Luzhin-Sonia and Svidrigailov-Sonia, this episode, too, involves the transfer of money. Luzhin's vile provocation fails, Svidrigailov's charitable-quasi-authorial—action succeeds, although it does so close to the novel's epilogue, thus not allowing for any further dramatic turns, whereas Aliosha's two-step combination not only does succeed in the heat of events, but also receives approval from above (the God and the Author) in the course of a special meta-discursive dialogue.

Meanwhile, Aliosha's script is structurally no less manipulative than, say, that of Kolia Krasotkin, who delays bringing Iliusha the retrieved pet Zhuchka—solely for the effect he considers beneficial (Book X; cf. the "Only five minutes late!" line in "A Gentle Spirit"). In a broader perspective, one cannot help drawing a comparison with the discourse of the Grand Inquisitor (which, incidentally, appears only four chapters later, in the same Book $\mathrm{V}$, and also within the framework of multi-level 'authorship'), whose problem is precisely manipulatively assuming responsibility for "these little ones"-allegedly in their own interest and with reliance on the Church and God. ${ }^{3}$ Bakhtinian metaphysical hermeneutics ${ }^{4}$ was to a certain degree motivated by the invisible and ineffable hidden image of God, ${ }^{5}$ being generally related to the common issue of religion par excellence. Mikhail Bakhtin himself, as we may gather from multiple memoirist sources, was deeply religious (no less than say, someone like Aleksey Losev). Many typical Bakhtinian concepts (including those of polyphony and dialogue) betray a concealed religious subtext- to one extent or another.

The 'God,' it is true, is provided with a dialogical opportunity to speak, but, as the Inquisitor observes correctly, "You have no right to add anything to what you have already said before" (V, 5; 14: 228). Despite this silence, however, the Author's subversion of the Inquisitor's script is evident. Aliosha, on the other hand, simply refers to the elder, on whose side, according to the novel's overall script, is God himself, thus cutting off the possibility of any further discussion. The polyphonic principle: "Trust in God, but do the right thing", is suddenly suspended. The 'firing' not only of pots, but also of men, turns out to be entrusted, with divine approval, to a kind of overman. This, contrary to Dostoevsky's and Bakhtin's refusal to stop the dialogue and be 'mechanistically final,' produces the categorical discursive effect of a deus ex machina.

But then, this deadend paradox, apparently so un-Dostoevskian, does stem from the very essence of the writer's favorite Scripture. Indeed, if 'fishers of men' (Matthew 4:19) are OK, why not those who fire clay pots, i.e., 'potters of men' as well?!

Funding: This research received no external funding. 
Acknowledgments: The author is happy to thank Dennis Ioffe and Frederick White for their kind assistance with the preparation of this text for print.

Conflicts of Interest: The author declares no conflict of interest.

\section{Notes}

1 Here, and below, for the sake of simplicity, the "Author" is perceived as the one who produces the "horizons of perception" (which are constantly in the proces of changing in the course of the narrative development). We employ this term in the sense of Wolfgang Iser (1978).

2 Bakhtin, naturally does not miss this passage and refers to it as an example of the fact that "[t]ruth turns out to be unjust if it touches upon some inner depths of someone else's personality," and places it in a class with two similar ones: Aglaya's remark to Myshkin in Idiot (III, 8; 8: 354) and Stavrogin's to Tikhon in Demons (III, 9; 11: 11). See (Bakhtin 1972, pp. 101-2).

3 On the transformation of Aliosha from "Son" into "Father", dealing with him as with the "author" of the Life of Zosimus and about the parallel between Zosimus and the Grand Inquisitor, see (Holquist 1977, pp. 177-97) ("[Zosima] has precisely the kind of power sought by Ivan's Grand Inquisitor"; p. 189). On the authority/compromise of the dicourses of characters in "The Brothers Karamazov" and on the 'vita-sanctorum'-type image-construction of Aliosha based on the hagiographic figure of Alexei the Man of God, in particular see (Vetlovskaia 1977).

4 On the suggestive issue of Bakhtinian hermeneutics and religion one may consult, see (Bagshaw 2016; Felch and Contino 2001; Mihailovich 1997; Coates 1999).

5 If to use this tellng expression borrowed from Bakhtin's younger Parisian contemporary Lucien Goldmann which was used in his seminal Marxist-religious celebrated monograph entitled Le dieu caché (Goldmann 1955).

\section{References}

Bagshaw, Hilary. 2016. Religion in the Thought of Mikhail Bakhtin. Reason and Faith. London: Routledge.

Bakhtin, Mikhail. 1972. Problemy Poetiki Dostoevskogo. Moscow: Khudozhestvennaia Literatura.

Bocharov, S. G. 1985. Perekhod ot Gogolia k Dostoevskomu. In O Khudozhestvennykh Mirakh. Moscow: Sovetskaia Rossiia.

Coates, Ruth. 1999. Christianity in Bakhtin: God and the Exiled Author. Cambridge: Cambridge University Press.

Dostoevsky, Fyodor M. 1972-1990. Polnoe Sobranie Sochinenii v Tridtsati Tomakh. Leningrad: Nauka.

Felch, Susan, and Paul Contino. 2001. Bakhtin and Religion: A Feeling for Faith (Rethinking Theory). Evanston: Northwestern University Press.

Gogol', Nikolai V. 1976-1979. Sobranie Sochinenii v Semi Tomakh. Moscow: Khudozhestvennaia Literatura.

Goldmann, Lucien. 1955. Le Dieu Caché: Etude sur la Vision Tragique dans les Pensées de Pascal et dans le Théâtre de Racine. Paris: Gallimard. Holquist, Michael. 1977. Dostoevsky and the Novel. Princeton: Princeton UP.

Iser, Wolfgang. 1978. The Act of Reading. A Theory of Aesthetic Response. Baltimore and London: The Johns Hopkins University Press.

Mihailovich, Alexandar. 1997. Corporeal Words: Mikhail Bakhtin's Theology of Discourse (Studies in Russian Literature and Theory). Evanston: Northwestern University Press.

Shifman, I. S., ed. 1993. Uchenie: Piatiknizhie Moiseevo. Moscow: Respublika.

Turgenev, Ivan S. 1961-1962. Sobranie Sochinenii v Desiati Tomakh. Moscow: Khudozhestvennaia Literatura.

Vetlovskaia, V. E. 1977. Poetica Romana Bratia Karamazovy. Leningrad: Nauka. 